\title{
3 次元経路制御手法の提案*
}

江上正 ${ }^{* 1}$, 福永彰彦*2

\section{A Proposal of Method of Path Control on 3-Dimensional Space}

\author{
Tadashi EGAMI*1 and Akihiko FUKUNAGA \\ ${ }^{* 1}$ Graduate School of Engineering, Kanagawa University \\ 3-27-1 Rokkakubashi, Kanagawa-ku, Yokohama, 221-8686 Japan
}

\begin{abstract}
We propose a method of a path control on 3-dimensional space in this paper. In the proposed methods, a desired point that is a minimum distance from the present position is searched and the straight line which connects its front and after points is provided as a base line. Multi-axial type mechanical systems are considered and the equations of motion in an orthogonal coordinate system are transformed to rotational and movement coordinate system. The transformed system can be decoupled and decomposed into a component of the direction of movement and a component of a plain which estimates a path error. Therefore, the control systems for the components can be separately constructed. Moreover, the effect of disturbance is absorbed by the control system for the component of the direction of movement and the disturbance of the path error becomes little. However, large delay of a time response occurs as a result. In this paper, the preview feedforward compensation is added for the control system of the component of the direction of movement to compensate for the delay. The proposed path control method has been applied to a multi-axis linear motor table and the effectiveness of the method is confirmed experimentally.
\end{abstract}

Key Words : Path Control, Preview Control, 3-Dimensional Space, Servo Mechanism, Motion Control

\section{1. 緒言}

経路制御とは，位置の軌跡を時間に依存しない与えられた経路に追従させることを目的とするものであり，時 間依存型の参照軌道に追従させる軌道制御とは本質的に異なるものである．経路制御の場合には，軌道制御と違 って，必ずしもどの時刻にどの場所にいるのかが要求されないため，軌道制御に比べて，軌跡からのずれを小さ くできる上, 入力のピーク值が抑えられ，入力の変動が滑らかになる点や外乱の影響も経路方向成分で吸収でき るなどの利点がある．つまり無理な動きをすることなく軌跡からのずれを小さくできることになる．移動車両や ロボットマニピュレータなどの多軸のメカニカルシステムにおいては，軌道制御よりもむしろこの経路制御が望 まれる場合も多い.しかし，そうはいってもどの時刻にどの場所にいるかということも作業効率の面からは重要 であり，上記の特性を活かした上で，時間目標值への追従性も兼衫備えるような経路制御手法の構築が必要とさ れる. また多くのメカニカルシステムでは 3 次元空間での運動が一般的であるので， 3 次元空間で扱う経路制御 が重要となってくる.

このような経路制御を目的とした研究としては, 軌道目標值を各軸目標值に分解し, 制御特性を予見制御や zero phase error tracking 制御など様々な手法でできるだけ一致させ, 各軸独立に位置制御を行うことで軌道制御を行う 方法が多く見られる苜 (4). しかし，この場合には本質的に経路制御そのものを考えているわけではないため，必 ずしも望ましい応答が得られるとは限らない. 外乱やパラメータ変動などにも対処できる本質的な経路制御とし

\footnotetext{
* 原稿受付 2011 年 3 月 26 日

*1 正員, 神奈川大学大学院工学研究科（广221-8686 神奈川県横浜市神奈川区六角橋 3-27-1)

*2 神奈川大学大学院工学研究科

E-mail: egami@kanagawa-u.ac.jp
} 
ては, 各軸独立ではなく他の軸の情報を用いながらの協調制御が望ましいと思われる.このような試みとしては, cross-coupled control を基本とした手法(9) (9)，面積誤差を導入した手法 ${ }^{(10),(11)}$ ，同期化制御を用いた手法 ${ }^{(12) \sim(15)}$ ，誤 差を進行方向と経路誤差方向に分離して扱う手法(16) (19)などが提案されている.

この中で文献(16)では，回転座標変換により誤差を進行方向と経路誤差方向に分離して制御を行っているが, 座標変換に動的な概念を用いていないため，真円のように進行方向と経路との角度が一定の場合はよいが，これ が逐次変化する場合は対応できないと考えられる．また一般概念的に論じているため，実際に 3 次元空間の任意 曲線経路に対して適用しようとすると具体的対応が難しいと思われる. これに対して, 著者らは，2 次元平面に おける任意曲線経路に対する経路制御に対して，回転座標変換と伸縮座標変換を用いて，任意曲線経路を逐次真 円経路あるいは直線経路に変換し，誤差を進行方向と経路誤差方向に分離して变換領域で正確に経路誤差を評価 するべクトル分解経路制御と呼んでいる手法を提案し, 実験により有効性の検討を行っている ${ }^{(17),(18)}$.この手法は, 進行方向と経路誤差方向を非干涉とでき, 経路誤差方向である半径方向および垂直方向成分の目標值を一定值と して扱えるものである.この手法を用いて，時間応答が遅いにもかかわらず経路誤差は小さくなるという特徽的 な結果が得られている。しかし, 経路目標值によって極座標系か直交座標系かの扱いを変える必要があるなどの 煩雑さが見られた．このため，目標経路を点列で与え，現在位置から目標経路上の最短点を探索して，これを基 準とした変換座標上で経路制御を行う最短目標点探索を用いた経路制御手法を新たに提案し，実験により有効性 の検討を行っている(19)．この手法によれば，ほぼ正確な経路誤差が評価でき，経路目標值による扱いの違いはな くなることになる.

そこで本論文では, 文献(19)の手法の考え方を発展させた 3 次元空間における経路制御手法を提案する. 本論文 では動的な回転及び移動座標変換により，システムを総移動距離軸で評価する進行方向とそれと垂直な平面上の 経路誤差方向に分離し，それぞれに適した制御系を構成する。一般にメカニカルシステムの制御を行う場合には 未来目標值は既知であることが多いため，進行方向の制御系には予見制御(20)を用いることにする．さらに提案手 法をリニアXYZテーブルに適用して，有効性を実験により検討する.

\section{2. 提案する 3 次元経路制御}

\section{$2 \cdot 1$ 最短目標点探索}

経路を離散的な点集合と考え，現在位置と離散化した目標点とを比較して，現在位置に最も近い目標点を探索 する．経路が連続的に与えられる場合には，離散的な時間目標值を設定することで点集合に分割する，そして， 前回求めた目標点 $\boldsymbol{R}(s)$ を基準とし, 現在位置 $\boldsymbol{p}(t)$ と最も近い目標点との距離 $E(t)$ を式(1)により算出し, そのと きの最短点を最短目標点 $\boldsymbol{R}(i)$ とする.

$$
E(t)=\min _{j}|\boldsymbol{R}(j+s)-\boldsymbol{p}(t)|
$$

ただし，

$s: 1$ 回前の最短目標点の番号(基準点)

$j:$ 探索番号 $(-h \leqq j \leqq h), 2 h+1:$ 探索点数

\section{$2 \cdot 2$ 回転移動座標変換}

次に, 前述した探索方法から求めた目標点を用いて, 回転移動座標変換を行う. 図 1 のように, 探索から求め た 3 次元経路上の最短目標点 $\boldsymbol{R}(i)$ とその前後の点 $\boldsymbol{R}(i-1), \boldsymbol{R}(i+1)$ を結ぶ線を $x-y$ 平面に投影し, その線と $x$ 軸 とのなす角を $\theta(t)$ とし，式(2)により $x_{1}-y_{1}$ 座標系に変換する.

$$
\left[\begin{array}{l}
x_{1}(t) \\
y_{1}(t)
\end{array}\right]=\left[\begin{array}{cc}
\cos \theta(i) & \sin \theta(i) \\
-\sin \theta(i) & \cos \theta(i)
\end{array}\right]\left[\begin{array}{l}
x(t) \\
y(t)
\end{array}\right]
$$

さらに, $\boldsymbol{R}(i-1)$ と $\boldsymbol{R}(i+1)$ を結ぶ線を $x_{1}-z$ 平面に投影し, その線と $x_{1}$ 軸とのな寸角 $\varphi(t)$ を求め, 式(3)により $d-q$ 座標系に変換する. 


$$
\left[\begin{array}{l}
d(t) \\
q(t)
\end{array}\right]=\left[\begin{array}{cc}
\cos \varphi(i) & \sin \varphi(i) \\
-\sin \varphi(i) & \cos \varphi(i)
\end{array}\right]\left[\begin{array}{c}
x_{1}(t) \\
z(t)
\end{array}\right]
$$

次に, $d$ 軸を $d$ 軸に平行で始点から探索により求めた $i$ 番目の目標点 $\boldsymbol{R}(i)$ までの目標点間距離の総和 $R_{l}(i)$ を成 分とする $l$ 軸に変換する. また， $y_{1}$ 軸に関しては， $y_{1}$ 軸に平行で $y_{1}$ 軸の誤差を成分とする $m$ 軸に， $q$ 軸も同様に $q$ 軸に平行で $q$ 軸の誤差を成分とする $n$ 軸にそれぞれ移動座標変換する. 以上の変換を行うことで $x-y-z$ 座標系 を図 2 に示す $l-m-n$ 座標系に変換することができる.

$$
\left[\begin{array}{c}
p_{l}(t) \\
p_{m}(t) \\
p_{n}(t)
\end{array}\right]=\left[\begin{array}{c}
p_{d}(t)-R_{d}(i)+R_{l}(i) \\
p_{y 1}(t)-R_{y 1}(i) \\
p_{q}(t)-R_{q}(i)
\end{array}\right]
$$

ただし,

$$
R_{l}(i)=R_{l}(s)+|\boldsymbol{R}(i)-\boldsymbol{R}(s)|
$$

このとき， $l$ 軸で進行方向を制御し,$m-n$ 平面上での現在位置と最短目標点間の距離を経路誤差として評価す る.また $l, m, n$ 軸は互いに非干渉であるので，相対的に $l$ 軸制御系をローゲインに， $m$ 軸と $n$ 軸の制御系をハ イゲインにすることで, 外乱などの影響を $l$ 軸で吸収でき, 経路誤差を抑制できると考えられる. そして, 経路 誤差 $e_{p}(t)$ と進行方向誤差 $e_{l}(t)$ はそれぞれ式(6), (7)で求まる. これによって正確な経路誤差評価が可能になる. ただし， $k$ は各サンプリング時刻を表す.

$$
\begin{gathered}
e_{p}(t)=\sqrt{\left[R_{m}(i)-p_{m}(t)\right]^{2}+\left[R_{n}(i)-p_{n}(t)\right]^{2}} \\
e_{l}(t)=R_{l}(k)-p_{l}(t)
\end{gathered}
$$

以下ではこの手法を具体的に説明する. 制御対象として一般の XYZ テーブルを想定する. このシステムの運 動方程式は式(8), (9)のようになる.

$$
\begin{gathered}
\dot{p}_{i}(t)=v_{i}(t) \\
\dot{v}_{i}(t)=-\frac{D_{i}}{M_{i}} v_{i}(t)+\frac{K_{F i}}{M_{i}} u_{c i}(t)-\frac{1}{M_{i}} d_{c i}(t)
\end{gathered}
$$

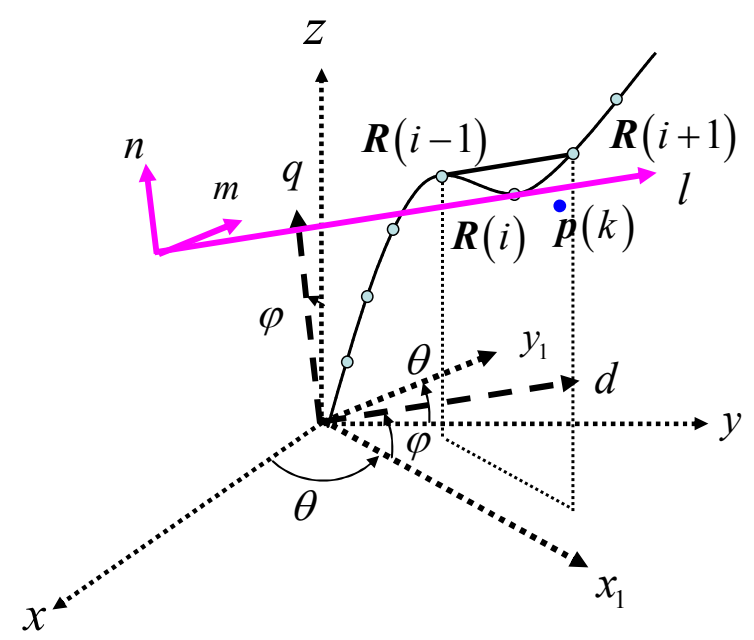

Fig.1 Rotational and movement coordinate transformations

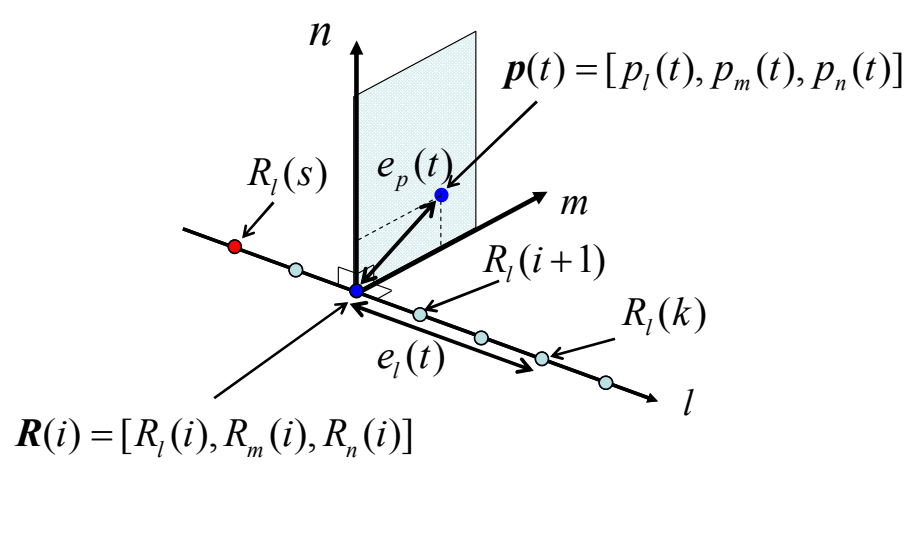

Fig. 2 l-m-n coordinate system 
ここで, $i=x, y, z$ であり,

$p_{i}(t)$ : 位置, $v_{i}(t)$ : 速度, $u_{c i}(t)$ : 電流指令入力, $d_{i}(t)$ : 負荷推力, $M_{i}$ : 質量 $[\mathrm{kg}], D_{i}$ : 粘性係数 $[\mathrm{Nm} / \mathrm{s}]$, $K_{F i}$ : 推力定数 $[\mathrm{N} / \mathrm{V}]$

である.

ここで質量, 摩擦係数, 推力定数の各パラメータは $x, y, z$ 軸で異なるため, 各係数を見かけ上一致させて共通の仮想的 なパラメータ $M, D, K_{F}$ を用いて表すと式(9) は以下のようになる. これは 3 次元空間上で移動する仮想的なパラメータを 持つテーブルの動きを各軸で表すことに相当する.

$$
\begin{aligned}
& \dot{v}_{i}(t)=-\frac{D}{M} v_{i}(t)+\frac{K_{F}}{M} u_{i}(t)-\frac{1}{M} d_{i}(t) \\
& =a v_{i}(t)+b u_{i}(t)+g d_{i}(t)
\end{aligned}
$$

ただし，

$$
u_{i}(t)=\frac{M K_{F i}}{M_{i} K_{F}}\left\{u_{c i}(t)-\frac{D_{i}}{K_{F i}} v_{i}(t)\right\}+\frac{D}{K_{F}} v_{i}(t) \quad d_{i}(t)=-\frac{M}{M_{i}} d_{c i}(t)
$$

式(2)〜(4)の変換手順を式(8)および(10)に適用すると $l, m, n$ 軸成分は，それぞれ以下のようになる.

[ $l$ 軸成分 $]$

$$
\begin{gathered}
\dot{p}_{l}(t)=\dot{p}_{d}(t)-\dot{R}_{d}(i)+\dot{R}_{l}(i)=v_{a l}(t) \\
\dot{v}_{a l}(t)=a v_{a l}(t)+b u_{a l}(t)+g d_{d}(t) \\
u_{a l}(t)=u_{d}(t)-\frac{a}{b}\left[\dot{\varphi}(t) p_{q}(t)-\dot{R}_{d}(i)+\dot{R}_{l}(i)\right]+\frac{1}{b}\left[\ddot{\varphi}(t) p_{q}(t)-\dot{\varphi}^{2}(t) p_{d}(t)+2 \dot{\varphi}(t) v_{q}(t)-\ddot{R}_{d}(i)+\ddot{R}_{l}(i)\right]
\end{gathered}
$$

[ $m$ 軸成分 $]$

$$
\begin{gathered}
\dot{p}_{m}(t)=-\dot{\theta}(t) p_{x 1}(t)+v_{y 1}(t)-\ddot{R}_{y 1}(i)=v_{a m}(t) \\
\dot{v}_{a m}(t)=a v_{a m}(t)+b u_{a m}(t)+g d_{y 1}(t) \\
u_{a m}(t)=u_{y 1}(t)+\frac{a}{b}\left[\dot{\theta}(t) p_{x 1}(t)+\dot{R}_{y 1}(i)\right]-\frac{1}{b}\left[\ddot{\theta}(t) p_{x 1}(t)+\dot{\theta}^{2}(t) p_{y 1}(t)+2 \dot{\theta}(t) v_{x 1}(t)+\ddot{R}_{y 1}(i)\right]
\end{gathered}
$$

$[n$ 軸成分 $]$

$$
\begin{gathered}
\dot{p}_{n}(t)=-\dot{\varphi}(t) p_{d}(t)+v_{q}(t)-\dot{R}_{q}(i)=v_{a n}(t) \\
\dot{v}_{a n}(t)=a v_{a n}(t)+b u_{a n}(t)+g d_{q}(t)
\end{gathered}
$$




$$
u_{a n}(t)=u_{q}(t)+\frac{a}{b}\left[\dot{\varphi}(t) p_{d}(t)+\dot{R}_{q}(i)\right]-\frac{1}{b}\left[\ddot{\varphi}(t) p_{d}(t)+\ddot{\varphi}^{2}(t) p_{q}(t)+2 \dot{\varphi}(t) v_{d}(t)+\ddot{R}_{q}(i)\right]
$$

式(11)〜式(16)に対して， $l$ 軸で進行方向誤差を評価し， $m-n$ 平面上で経路誤差を評価できるで， $R_{l}(k)$ を進行 方向目標值と寸れば, $m$ 軸及び $n$ 軸の目標值は 0 になるので, それぞれ $p_{l}(t) \rightarrow R_{l}(k), p_{m}(t) \rightarrow 0, p_{n}(t) \rightarrow 0$ とな るような制御を行えば経路制御が実現できる.

\section{$2 \cdot 3$ 制御系の構成}

制御系としてはどのような制御系を用いることも可能であるが，本稿では，式(11)〜(16)を離散時間系に変換し た後, 最適ディジタルサーボ系をベースとした制御系を構成する， $l, m, n$ 軸は互いに非干涉であるので，相対 的に $l$ 軸をローゲイン, $m$ 軸と $n$ 軸をハイゲインの最適サーボ系とすることで, 外乱などの影響を $l$ 軸で吸収で き，経路誤差を抑制できると考えられる.

しかしこの場合, $l$ 軸の追従性が劣ることにより,$l$ 軸の応答の時間遅れが無視できなくなり, また突発的な外 乱に対して $l$ 軸方向に大きな応答の乱れを生じる恐れがある. そのため，予見フィードフォワード補償を行うこ とにより，外乱の吸収特性を損なわず各軸の時間応答の遅れを改善することを考える ${ }^{(20)}$. したがって, $l$ 軸に関 してはローゲインの最適予見サーボ系を構成し， $m$ 軸と $n$ 軸に関してはハイゲインの最適サーボ系を構成するこ とで対処する.

以下 $l$ 軸を例として説明する. 式(11), (12)を状態方程式表現し, 離散化したものを次のように表す.

$$
\begin{gathered}
\boldsymbol{x}(k+1)=\boldsymbol{A} \boldsymbol{x}(k)+\boldsymbol{b} u(k)+\boldsymbol{g} d(k) \\
y(k)=\boldsymbol{c x}(k)
\end{gathered}
$$

ただし, $\quad \boldsymbol{x}(k)=\left[\begin{array}{c}p_{l}(k) \\ v_{a l}(k)\end{array}\right], u(k)=u_{a l}(k), d(k)=d_{d}(k), y(k)=p_{l}(k)$

多くのメカニカルシステムでは，目標值信号は予め与えておくことが一般的であるため，制御開始時には追従 すべき未来目標值は既知であると考えられる.このため $l$ 軸の目標值信号 $R_{l}(k)$ から $M_{R}$ ステップ先までの目標值 信号が既知であるとする．また $m$ 軸と $n$ 軸の目標值信号は 0 とする．この目標值信号に対して以下の誤差信号を 定義する.

$$
\text { 誤差信号 }: e_{l}(k)=R_{l}(k)-p_{l}(k)
$$

いま式(18)に対して次のような入力むだ時間補償を含むエラーシステムを導出する．ただし， $\Delta$ は 1 階差分オぺ レータを表す。

$$
\left[\begin{array}{c}
e_{l}(k+1) \\
\Delta \boldsymbol{x}(k+1) \\
\Delta u(k)
\end{array}\right]=\left[\begin{array}{ccc}
1 & -\boldsymbol{c} \boldsymbol{A} & -\boldsymbol{c} \boldsymbol{b} \\
0 & \boldsymbol{A} & \boldsymbol{b} \\
0 & 0 & 0
\end{array}\right]\left[\begin{array}{c}
e_{l}(k) \\
\Delta \boldsymbol{x}(k) \\
\Delta u(k-1)
\end{array}\right]+\left[\begin{array}{l}
0 \\
0 \\
1
\end{array}\right] \Delta u(k)+\left[\begin{array}{l}
1 \\
0 \\
0
\end{array}\right] \Delta R_{l}(k+1)+\left[\begin{array}{c}
-\boldsymbol{c g} \\
\boldsymbol{g} \\
0
\end{array}\right] \Delta d(k)
$$

あるいは

$$
\boldsymbol{X}_{0}(k+1)=\boldsymbol{\Phi} \boldsymbol{X}_{0}(k)+\boldsymbol{\Gamma} \Delta u(k)+\boldsymbol{\Gamma}_{R} \Delta R_{l}(k+1)+\boldsymbol{\Gamma}_{d} \Delta d(k)
$$

評価関数を次式のように定義する. 


$$
J=\sum_{k=-M_{R}+1}^{\infty}\left[q_{e} e^{2}(k)+q_{p}\left\{\Delta p_{l}(k)\right\}^{2}+q_{v}\left\{\Delta v_{a l}(k)\right\}^{2}+h\{\Delta u(k)\}^{2}\right]=\sum_{k=-M_{R}+1}^{\infty}\left[\boldsymbol{X}_{0}^{T}(k) \boldsymbol{Q} \boldsymbol{X}_{0}(k)+h\{\Delta u(k)\}^{2}\right]
$$

ただし，

$$
\boldsymbol{Q}=\left[\begin{array}{llll}
q_{e} & & & \\
& q_{p} & & \\
& & q_{v} & \\
& & & \mathbf{0}
\end{array}\right] \geq 0, \quad h>0
$$

式(20)を最小にするような予見制御入力は以下のように求められる ${ }^{(20)}$.

$$
\begin{aligned}
\Delta u(k) & =\boldsymbol{f}_{0}(k)+\sum_{j=1}^{M_{R}} f_{R}(j) \Delta R(k+j) \\
& =f_{e} e(k)+f_{p} \Delta p_{l}(k)+f_{v} \Delta v_{a l}(k)+f_{u} \Delta u(k-1)+\sum_{j=1}^{M_{R}} f_{R}(j) \Delta R(k+j)
\end{aligned}
$$

ただし，

$$
\begin{aligned}
& \boldsymbol{f}=\left[\begin{array}{llll}
f_{e} & f_{p} & f_{v} & f_{u}
\end{array}\right]=-\left[h+\boldsymbol{\Gamma}^{T} \boldsymbol{P} \boldsymbol{\Gamma}\right]^{-1} \boldsymbol{\Gamma}^{T} \boldsymbol{P \Phi} \\
& \boldsymbol{f}_{R}(j)=-\left[h+\boldsymbol{\Gamma}^{T} \boldsymbol{P} \boldsymbol{\Gamma}\right]^{-1} \boldsymbol{\Gamma}^{T}\left(\xi^{T}\right)^{j-1} \boldsymbol{P} \boldsymbol{\Gamma}_{R}(\xi=\boldsymbol{\Phi}+\boldsymbol{\Gamma} \boldsymbol{f}) \\
& \boldsymbol{P}=\boldsymbol{Q}+\boldsymbol{\Phi}^{T} \boldsymbol{P} \boldsymbol{\Phi}-\boldsymbol{\Phi}^{T} \boldsymbol{P} \boldsymbol{\Gamma}\left[h+\boldsymbol{\Gamma}^{T} \boldsymbol{P} \boldsymbol{\Gamma}\right]^{-1} \boldsymbol{\Gamma}^{T} \boldsymbol{P} \boldsymbol{\Phi}
\end{aligned}
$$

$l$ 軸制御系のブロック線図を図 3 に示寸。なお， $m$ 軸と $n$ 軸の制御入力は式 $(21)$ から予見フィードフォ ワード項を除いたものを用いる.

\section{3. 実験による検討}

本論文で提案する 3 次元経路制御を図 4 のようなリニアXYZテーブルに適用して実験による検討を行った. 今回用いる リニアXYZテーブルは図４に示すようにリニアブラシレスモータを十字型に組み合わせ，さらにZ 軸を追加したものであ る.このリニアXYZテーブルの状態方程式は式(8)および(9)に示すようであり，パラメータは以下のようになる.

X軸：

ストローク : $0.6 \mathrm{~m}$, 可動子質量 : $26.1 \mathrm{~kg}$,

粘性係数: $14.93 \mathrm{~kg} / \mathrm{s}$, 推力定数 : $29.722 \mathrm{~N} / \mathrm{A}$

Y軸：

ストローク : $0.6 \mathrm{~m}$, 可動子質量 : $13.9 \mathrm{~kg}$,

粘性係数: $0.2 \mathrm{~kg} / \mathrm{s}$, 推力定数: $49.855 \mathrm{~N} / \mathrm{A}$

Z 軸 :

ストローク : $0.4 \mathrm{~m}$, 可動子質量 : $1.5 \mathrm{~kg}$,

粘性係数: $0.1 \mathrm{~kg} / \mathrm{s}$, 推力定数: $51.318 \mathrm{~N} / \mathrm{A}$ 
Preview feedforward compensation



Fig. 3 Block diagram of control system of $l$-axis

また駆動回路への入力電圧の制限は $x$ 軸については-10V〜+10V であり， $y$ 軸については-3 V +3 V,$z$ 軸については- $1 \mathrm{~V}$ 〜+1 V とした. 今回各軸の制御系特性をできるだけ一致させた各軸独立制御との応答の比較を行った.

各軸独立制御は式(10)の形に変形して両軸の平均值を見かけ上のパラメータとし，離散時間系に変換して，2・2で $l$ 軸 を $x$ 軸， $y$ 軸あるいは $z$ 軸として同様な手順によりディジタル最適サ一ボ系を構成している. また Z 軸は重力や摩擦など の影響を受けやすいため，これらの影響を軽減するためにあらかじめ外乱才ブザーバを用いている.

今回, 提案した 3 次元経路制御と各軸独立制御を比較検討する. 用いた評価関数の重みおよびフィードバック係数は以下 のようになる.

探索を用いた経路制御系 :

$l$ 軸: $\quad q_{e}=0.005, q_{p}=2500, q_{v}=0.01, h=10 \quad\left[\begin{array}{llll}f_{e} & f_{p} & f_{v} & f_{u}\end{array}\right]=\left[\begin{array}{llll}0.02 & -19.7 & -3.43 & -0.01\end{array}\right]$

$m, n$ 軸： $q_{e}=50, q_{p}=0.01, q_{v}=0.01, h=10 \quad\left[\begin{array}{llll}f_{e} & f_{p} & f_{v} & f_{u}\end{array}\right]=\left[\begin{array}{llll}2.19 & -231 & -12.2 & -0.04\end{array}\right]$

各軸独立制御系：

$x, y, z$ 軸: $q_{e}=0.20, q_{p}=500, q_{v}=1, h=1 \quad\left[\begin{array}{llll}f_{e} & f_{p} & f_{v} & f_{u}\end{array}\right]=\left[\begin{array}{llll}0.44 & -83.7 & -7.30 & -0.02\end{array}\right]$

実験では，上述したように探索を用いた経路制御の $l$ 軸の誤差の評価を相対的に小さく, $m, n$ 軸の誤差の評価をより 大きくして両者の制御系の特性を大きく変化させている. 目標経路は $x(t)=0.1 \cos \frac{2 \pi}{5} t, y(t)=0.1 \sin \frac{2 \pi}{5} t$, $z(t)=0.1 \sin \frac{\pi}{5} t$ として $t=0 \sim 10 s$ とした. このとき $l$ 軸目標值の総和 $R_{l}(i)$ は $1.33 \mathrm{~m}$ となり, サンプリング周期は $1 \mathrm{~ms}$ として目標点列はサンプリング周期単位とし，目標点列数 $10^{4}$ 個，目標点列間隔は $1.33 \times 10^{-4} \mathrm{~m}$ となる. また探索点数は 基淮点の前後それぞれ 2000 点としている.

図 5 に $l$ 軸制御系の予見ステップ数を決定するために予見ステップ数と評価関数值の割合を計算したグラフを示す.この 結果から予見ステップ数は 2000 とした.

図6〜8に $z$ 軸が $0.1 \mathrm{~m}$ を超えたとき， $y$ 軸方向に $10 \mathrm{~N}$ 相当のパルス状外乱を $1.5 \mathrm{~s}$ 間加えたときの実験結果を示寸. 図 6 は提案している 3 次元経路制御手法を用いた場合, 図 7 は図 6 の進行方向成分に通常の最適サ一ボ系を用いた場合, 図 8 は各軸独立制御を用いた場合を示寸それれ゙れ（a）経路応答，（b）経路誤差，（c） $l$ 軸応答，（d） $m-n$ 平面上の 応答，（e ） X 軸位置応答，（f） Y 軸位置応答，（g） Z 軸位置応答，（h） X 軸入力，（i ） Y 軸入力，（j） Z 軸 入力を示している. なお, 図6では (a ) に外乱の印加場所及び方向, (f) に印加した時刻及び方向を矢印で示している.

図 6，7 と図 8 を比較すると図6，7の提案している経路制御の方が大幅に経路誤差を低減できていることがわかる. とくに外乱印加時の応答の乱れに対しては, 経路制御では各軸が協調して経路誤差の低減が図られていることがわかる.ま 
た図 7 では図 8 と比べて各軸の応答が大幅に遅れているのに対して, 進行方向に予見フィードフォワード補償を用いた図 6 では, 図 8 と同程度まで応答の遅れが小さくなっているのがわかる.さらに図 6 と 7 では, 経路誤差も各軸の応答もほとん ど同じで，図6は図7に比へて応答の遅れの久を補正したものになっていることもわかる. 提案している経路制御手法は, 進行方向の追従性を劣化させることにより, 外乱の影響を進行方向で吸収して, 経路誤差を低减するのがひとつの特徵であ るため, 進行方向の応答の遅れは避けられなかったが予見を用いることにより, この特徽を維持したまま応答の遅れの大幅 な改善が可能になることが示せたと言える.

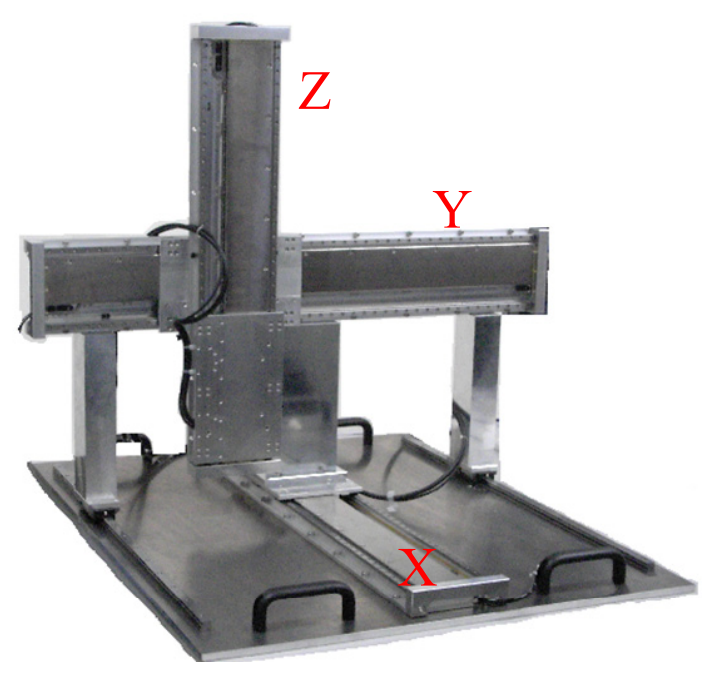

Fig.4 3-dimentional linear XYZ table

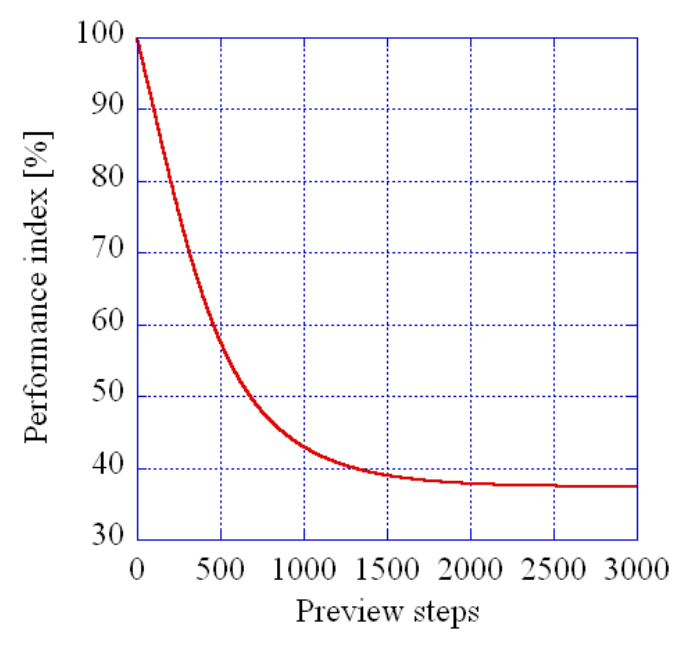

Fig.5 Performance index versus preview steps

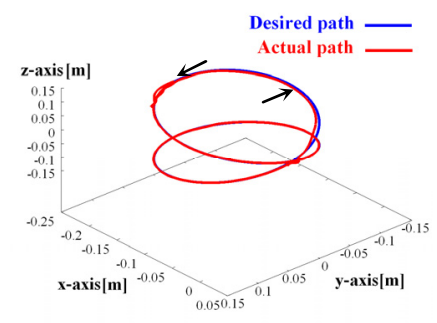

(a) Path

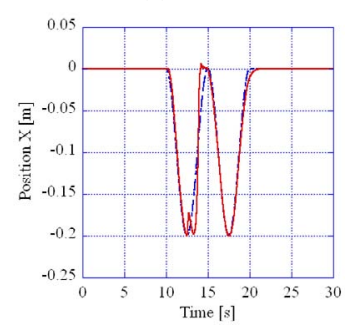

(e) Position X

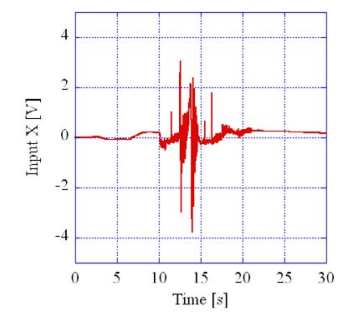

(h) Input Y

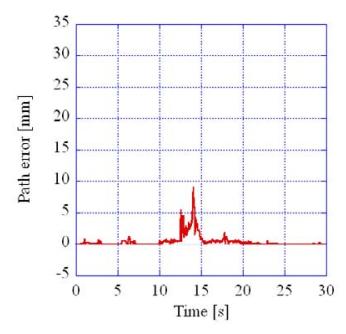

(b) Path error

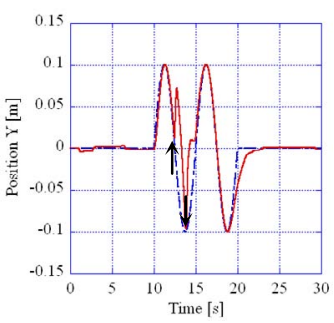

(f) Position Y

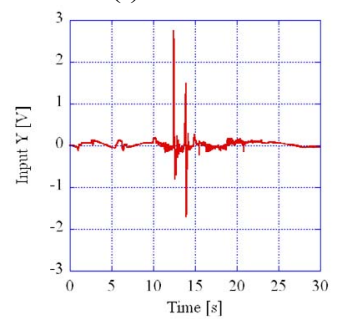

(i) Input $Y$

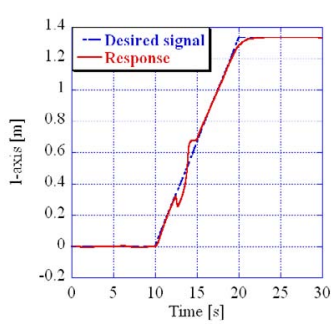

(a)l-axis

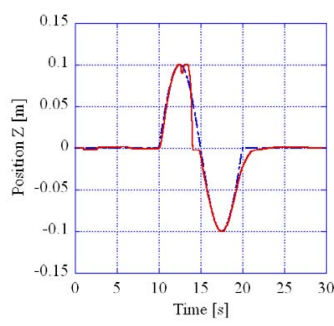

(g) Position Z

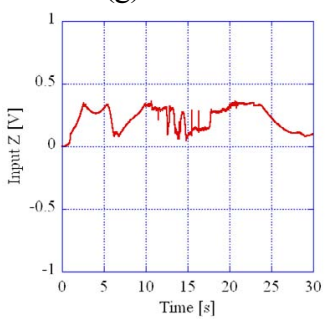

(j) Input Z

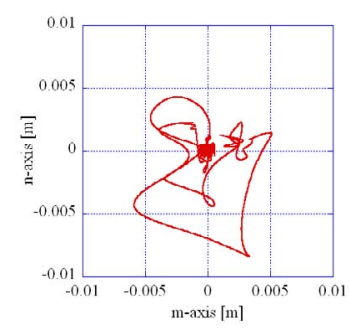

(d) m-n plane

Fig. 6 Proposed path control(with preview compensation) 


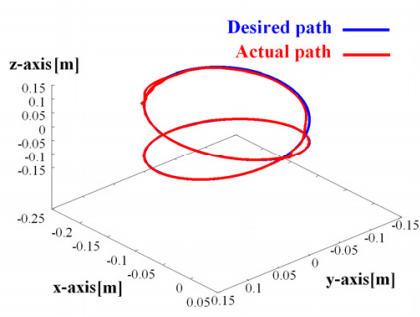

(a) Path

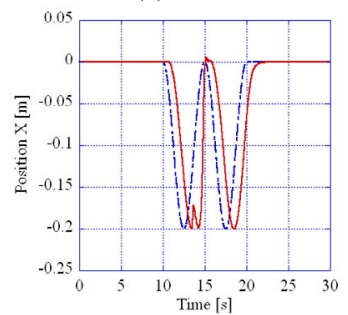

(e) Position X

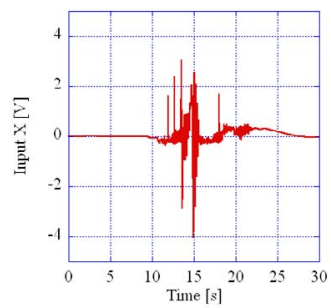

(h) Input X

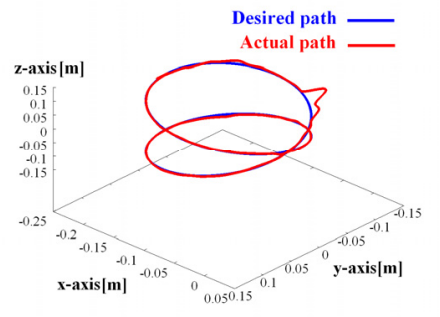

(a) Path

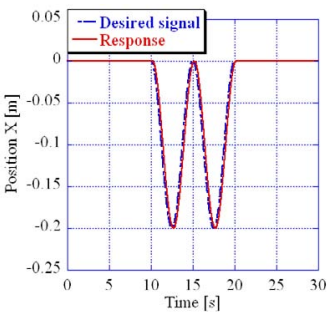

(e) Position X

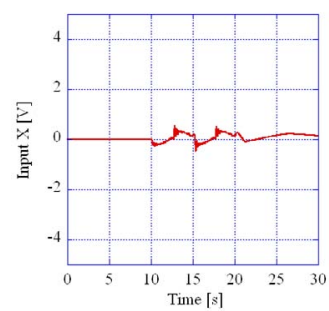

(h) Input X

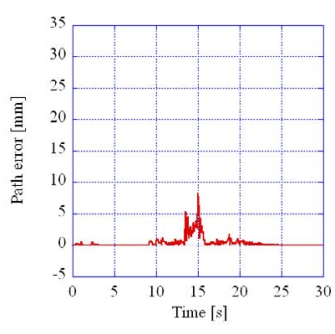

(b) Path error

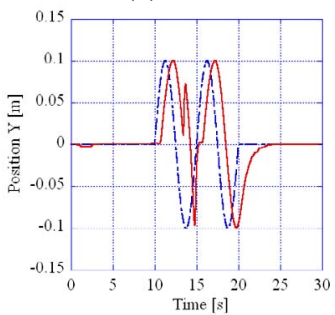

(f) Position Y

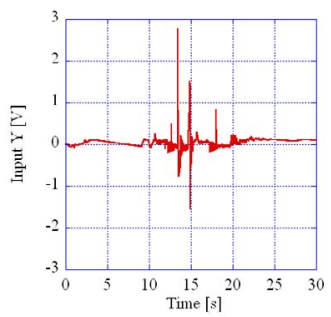

(i) Input $Y$

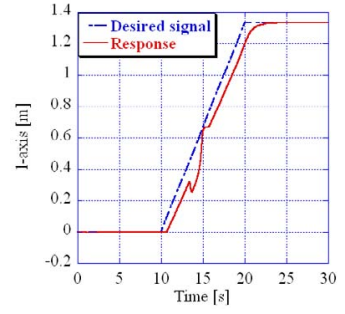

(c) 1-axis

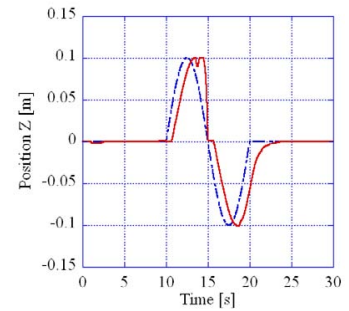

(g) Position Z

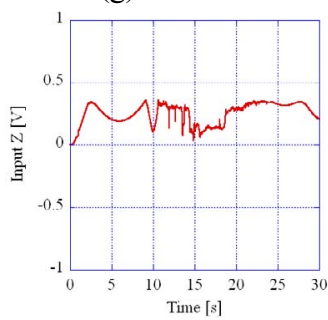

(j) Input Z

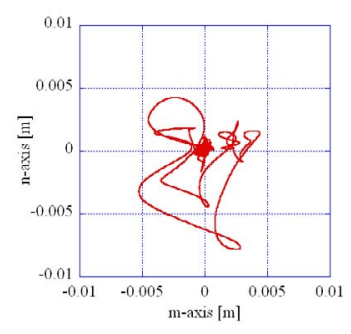

(d) m-n plane

Fig. 7 Path control (without preview compensation)

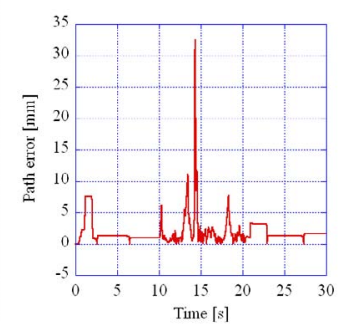

(b) Path error



(f) Position Y

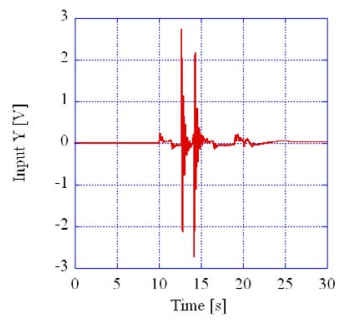

(i) Input $Y$

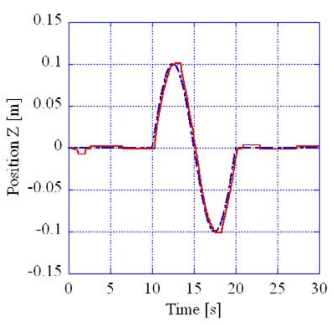

(g) Position Z



(j) Input Z

Fig.8 Independent control 


\section{4. 結 語}

本論文では，メカニカルシステムに対して 3 次元空間における本質的な経路制御を実現する手法として， 3 次 元経路制御手法を提案し，実験によりその有効性を示した.さらに進行方向に予見フィードフォワード補償を行 うことにより，経路制御の特徵を維持しながら応答の遅れを補正できることも示した.

メカニカルシステムにおいては 3 次元空間での運動が一般的であるので，提案する 3 次元経路制御は，ロボッ トマニピュレータやNC工作機械などにおける応用が期待される.

\section{文献}

(1) Tomizuka, M., Dornfeld, D. and Purcell, M., "Application of Microcomputers to Automatic Weld Quality Control", Transactions of the ASME, Journal of Dynamic systems, Measurement, and Control, Vol.102(1980), pp.62-68.

(2) Egami, T. and Tsuchiya, T.," Disturbance Suppression Control with Preview Action of Linear DC Brushless Motor", IEEE Transactions on Industrial Electronics, Vol.42, No.5(1995), pp.494-500.

(3) Tsao, T.C. and Tomizuka, M., "Adaptive Zero Phase Error Tracking Algorithm for Digital Control”, Transactions of the ASME, Journal of Dynamic systems, Measurement, and Control, Vol.109(1988), pp.349-354.

(4) Yeh, S.S. and Hsu, P.L., "Perfectly Matched Feedback Control and Its Integrated Design for Multiaxis Motion Systems", Transactions of the ASME, Journal of Dynamic systems, Measurement, and Control, Vol.126(2004), pp.547-557.

(5) Koren, Y., "Cross-Coupled Biaxial Computer Controls for Manufacturing Systems", Transactions of the ASME, Journal of Dynamic systems, Measurement, and Control, Vol.102(1980), pp.265-272.

(6) Kulkarni, P.K. and Srinivasan, K., "Optimal Contouring Control of Multi-Axial Feed Drive Servomechanisms", Transactions of the ASME, Journal of Engineering for Industry, Vol.111(1989), pp.140-148.

(7) Srinivasan, K. and Kulkarni, P.K., "Cross-Coupled Control of Biaxial Feed Drive Servomechanisms", Transactions of the ASME, Journal of Engineering for Industry, Vol.112(1989), pp.225-232.

(8) Koren, Y. and Lo, C.C., "Variable-gain cross-coupling controller for contour", Annals of the CIRP, Vol.40 (1991), pp.371-373.

(9) Chuang, H.Y. and Liu, C.H., "Cross-coupled Adaptive Feedrate Control for Multiaxis Machine Tools", Transactions of the ASME, Journal of Dynamic systems, Measurement, and Control, Vol.113(1991), pp.451-457.

(10) 伊藤浩司, 土谷武士, “面積誤差項を含む予見制御系の経路制御への応用”, 計測自動制御学会論文, Vol.25, No.7(1989), pp.771-777.

（11）江上正, 豊田 修, 土谷武士, “協調経路制御とそのリニアXーYテーブルへの応用”, 電気学会論文誌 $D$, Vol.113, No.12(1993), pp.1395-1402.

(12) Tomizuka, M., Hu, J.S. and Chiu, T.C., "Synchronization of Two Motion Control Axes Under Adaptive Feedforward Control", Transactions of the ASME, Journal of Dynamic systems, Measurement, and Control, Vol.114(1992), pp.196-203.

(13) 譚躍鋼，江上正，村田年昭，“最適同期化経路制御系とそのリニアXーYテーブルへの応用”，日本機械学会論文集 C編，Vol.62，No.598(1996)，pp.2193-2200.

(14) 中村政俊, 冷水大作, 久良修郭, “主軸従軸関係をもつメカトロサーボ系の主軸位置同期を図った高精度輪郭制御 法”，計測自動制御学会論文集，Vol.33，No.4(1997)， pp. 274-279.

（15）江上正，依田一宏,”メカトロサーボ系の最適同期化経路制御”，計測自動制御学会論文集，Vol.34， No.9(1998) pp.1178-1183.

(16) Ho, H.C., Yen , J.Y. and Lu, S.S.," A decoupled path-following control algorithm based upon the decomposed trajectory error", Mechanical Tools \& Manufacture, Vol.39(1999), pp.1619-1630.

(17) 江上正, 吉川智康, 栗原真, “ベクトル分解経路制御”, 電気学会論文誌D, Vol.120, No.2(2000), pp.262-268.

(18) Egami, T. and Tsuchiya, T., "Path Control with Vector Decomposition”, in Proc. Control 2000,(2000).

(19）田坂泰久, 江上正, “探索を用いた経路制御手法の提案とその応用”, 日本機械学会論文集 C 編, Vol.73, No.732(2007), pp.2238-2245.

（20）土谷武士，江上正，ディジタル予見制御，(1992)，産業図書. 